\title{
Taraxacum dooguei and T. dudmanianum (Asteraceae) - two new species from Britain and Ireland
}

\author{
A.J. Richards \\ Hexham, UK
}

Corresponding author: hightreesgarden@btinternet.com

This pdf constitutes the Version of Record published on $16^{\text {th }}$ September 2021

\begin{abstract}
Two new species of Taraxacum are described: T. dooguei A.J. Richards, a section Celtica species from Ireland related to T. pietii-oosterveldii, and T. dudmanianum A.J. Richards, a section Taraxacum species from Britain and Ireland previously incorrectly recorded as T. aberrans. Notes are given on their ecology and distribution.
\end{abstract}

Key words: Netherlands; Section Celtica; Section Taraxacum; Taraxacum aberrans auct. Angl.

\section{Introduction}

While preparing the forthcoming BSBI Field Handbook to British and Irish Dandelions (Richards, 2021), it became clear that it was necessary to describe two new species. These are described and discussed below.

Taraxacum dooguei A.J. Richards sp. nov.

Holotype: Flood debris line, lake shore, Saint's Island, Lough Ree, Co. Longford (v.c.H24), Ireland, N0756, 10/05/2018, D. Doogue no. 2018/26; DBN. Isotype: NMW. (Fig. 1).

Plant small to medium-sized with ascending, rather flat, homophyllous leaves. Leaves mid-green, lanceolate, unblotched, sometimes with sparse black spots on the upper surface, scarcely hairy, mid-rib purple proximally, becoming greener distally; petioles unwinged at the base, purple. Lateral leaf-lobes 3-5, recurved, triangular, acute, mostly entire. Terminal leaf-lobes triangular, shortly sagittate, acute, entire. Scapes equalling leaves, semi-decumbent, slightly hairy below the capitula, purplish. Exterior bracts 7-10 x 2.5-3.3 mm, erect to appressed, dark green suffused purplish externally, not pruinose, narrowly and inconspicuously bordered. Capitula 30-35 mm diameter, deep yellow. Ligules short, scarcely exceeding inner bracts, striped purple with purple teeth and inner florets tipped reddish. Stigmas discoloured, drying dark; pollen absent. Achene body $4.0 \mathrm{~mm}$, straw-coloured, rugose almost throughout; cone 0.2-0.3 mm. 


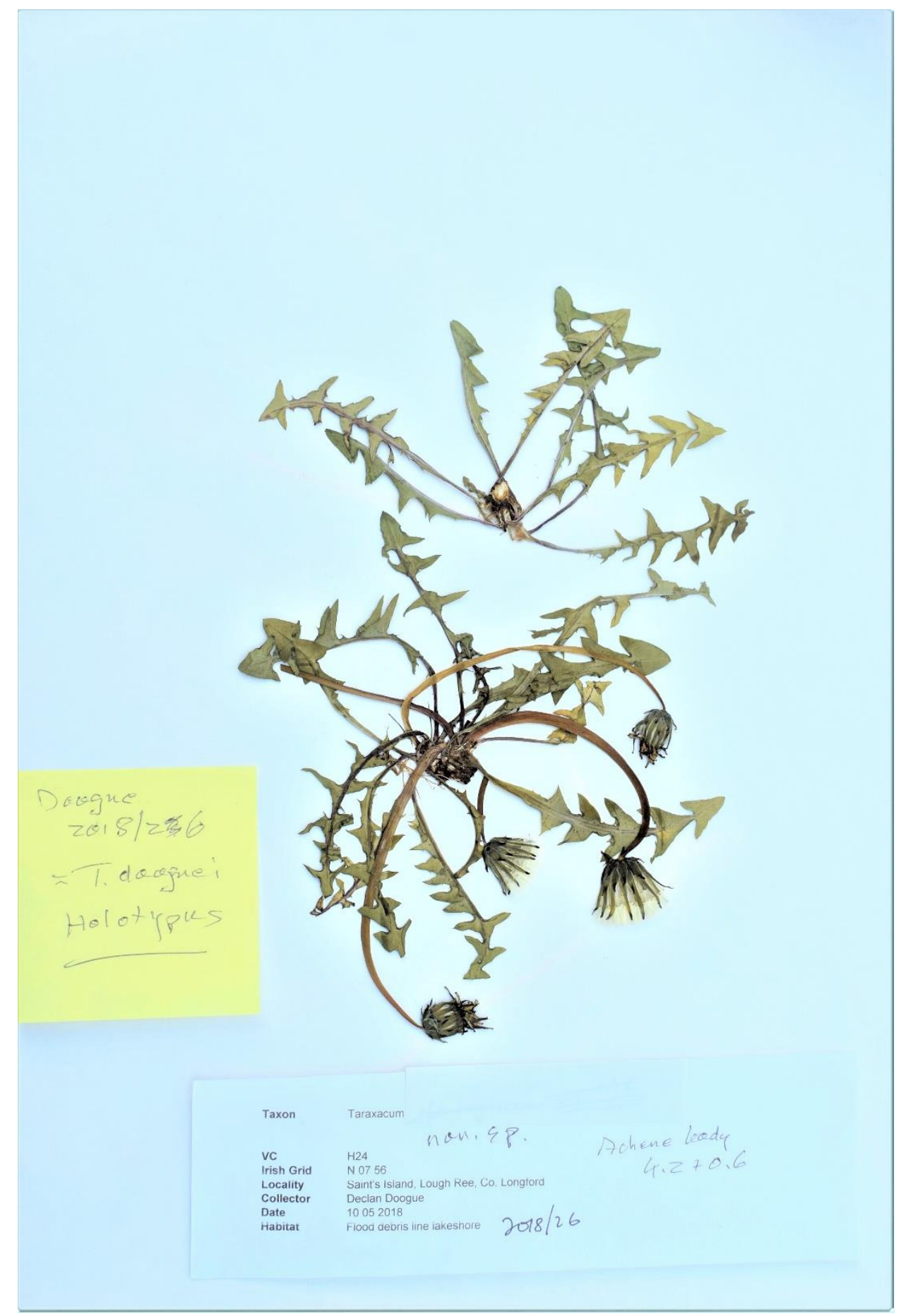

Figure 1. Holotype of T. dooguei (DBN)

In April 2009, I was invited by Declan Doogue to visit Dublin, and we spent several days on Taraxacological expeditions into central Ireland. Amongst other sites, we visited the rich wetlands around Faughalstown Holy Well, Lough Derravaragh (N4465) (v.c.H23, Westmeath) and Lough Ree (Westmeath and v.c.H24, Co. Longford) where the section Palustria $(\mathrm{H}$. Lindb.) Dahlst. species T. amarellum Kirschner \& Štěpánek and several other Irish endemics occur (Richards \& Doogue, 2017). Here we found a plant which was initially but rather hesitantly identified as $T$. anglicum Dahlst., a rare section Palustria species of fen meadows in England, France 
and the Netherlands. It had previously been collected there by Doogue in 2006. Smaller but similar material collected later from Lough Ree, v.c.H23 (N0653 and N0956) was not identified, but given a tentative workname 'T. non-texelense'.

Later in 2015, and again in 2018, Doogue collected similar but better material from Saint's Island, Lough Ree (N0756) (v.c.H24, Co. Longford), and in 2019 from the Great Heath of Maryboro (N5301) in Laois (v.c.H14). This was found to differ from $T$. anglicum in several characteristics, notably by having more pairs of lateral leaf-lobes, shorter ligules, an absence of pollen, narrower exterior bracts and larger achenes. It was originally given the workname 'T. turloughense', but is now being described as a new species T. dooguei in section Celtica A.J. Richards. Its closest relative is considered to be $T$. pietii-oosterveldii $\mathrm{H}$. Øllg., a species which had not been described in 2015, but is currently known to be widespread and frequent through much of Ireland and west Wales in wet habitats, and is also found rarely, perhaps introduced, in England, Netherlands and Denmark. T. dooguei and T. pietiioosterveldii are relatives of $T$. nordstedtii Dahlst., sometimes distinguished by Netherlands botanists as central to an informal subgroup 'Frugalia'.

In common with other members of the $T$. nordstedtii group, $T$. dooguei has short ligules with a solid brownish-purple stripe, which scarcely exceed the inner bracts. Like $T$. pietii-oosterveldii, pollen is absent and the stigma branches dry blackish. It differs from $T$. pietii-oosterveldii, with which it sometimes occurs, principally by lacking the abruptly, even acutely, angled distal margin to the lateral leaf-lobes. In fact the lateral lobe distal margins are usually straight, unlike those of both $T$. pietii-oosterveldii and $T$. nordstedtii, so that the reflexed leaf lobes appear sagittate. The achenes are larger than those of $T$. nordstedtii, but similar in size to those of $T$. pietii-oosterveldii although more rugose throughout and with a shorter cone. Unlike $T$. pietii-oosterveldii the leaves sometimes have small black spots on the upper surface. Both T. pietii-oosterveldii and T. dooguei have narrower exterior bracts than those of $T$. nordstedtii, darker stigmas, and, unlike the latter species, the bracts are not pruinose. T. olgae, endemic to the Solway Firth districts of England and Scotland, is similar to T. dooguei in many ways, and shares a tendency to produce small scattered black spots on the upper leaf surface, but has much smaller achenes and fewer pairs of lateral leaf lobes. The subsagittate leaves of $T$. dooguei are distinctive and reminiscent of T. akteum Hagend., Soest \& Zevenb. which is not a member of the $T$. nordstedtii alliance and has spreading exterior bracts and longer ligules. British plants originally identified with T. texelense Hagend., Soest \& Zevenb are now considered to be $T$. akteum.

Taraxacum dooguei grows in and at the margins of permanently or seasonally wet highly calcareous lake margins where it is often accompanied by the section Palustria species T. amarellum and T. webbii A.J. Richards. At present it is known from five sites in central Ireland (Fig. 2), as follows:

Lake shore with outcropping limestone, Saint's Island. Lough Ree, Co. Longford (v.c.H24), Ireland, N0756, 10/05/2015, D. Doogue no. 2015/146; DBN. Muckanagh, E shore of Lough Ree, Co. Longford (v.c.H24), N069535, 04/2009, D. Doogue and A.J. Richards; DBN. Derrynabuntale, shore of Lough Ree, Co. Longford (v.c.H24), N099564, 04/2009, D. Doogue \& A.J. Richards; DBN. The Great Heath of Maryboro', Co. Laois (v.c.H14) N5301, 30/04/2019. D. Doogue nos. 2019/144, 145; DBN. Small very wet marsh on the east side of Lough Derravaragh near a holy well in Faughalstown townland, Co. Westmeath (v.c.H23), N4465, 01/05/2006, D. Doogue 
no. 2021/35; DBN. Ditto, 04/05/2014, D. Doogue no. 2021/27; DBN. Ditto 04/2009, D. Doogue \& A.J. Richards; DBN.

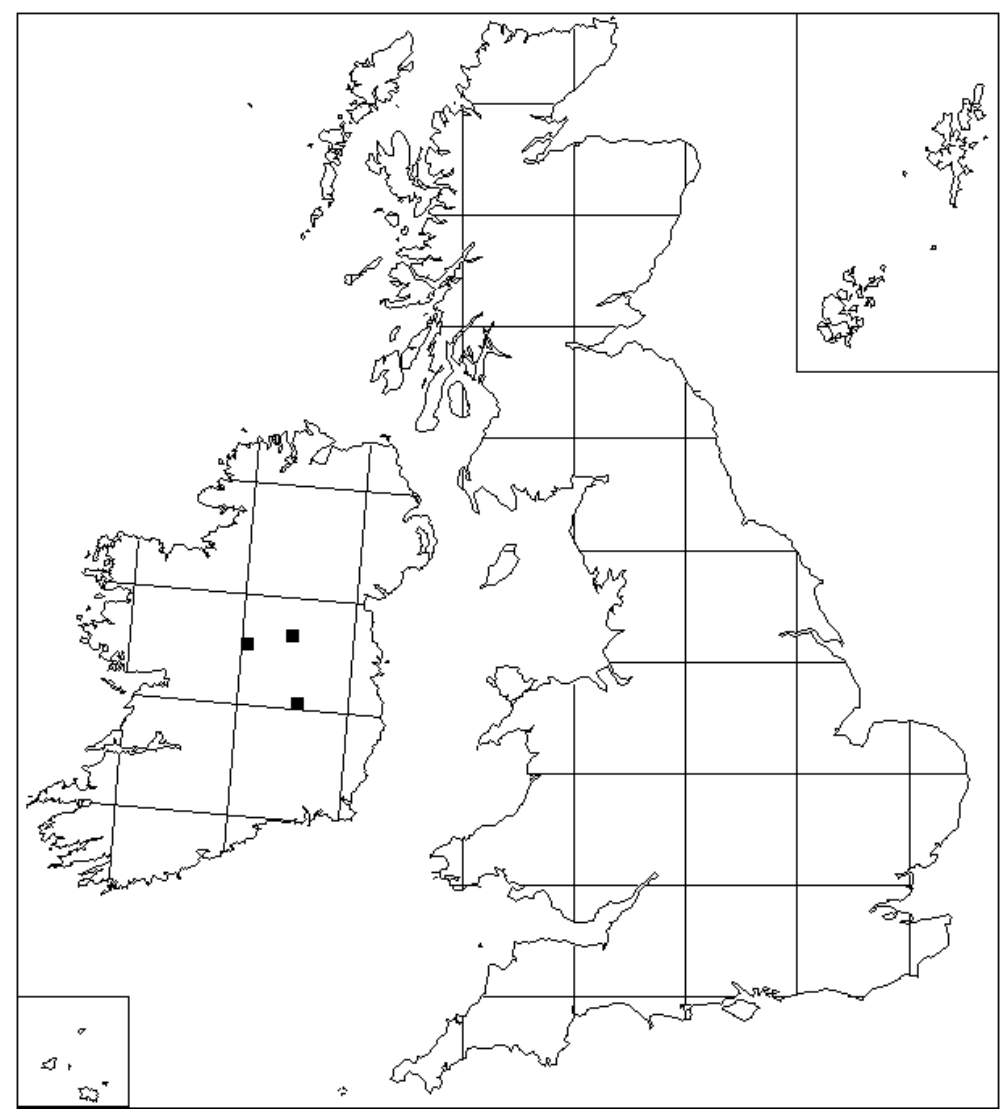

Figure 2. Distribution of $T$, dooguei

Taraxacum dooguei celebrates Dr. Declan Doogue whose copious collections, and encouragement of other Irish botanists to collect likewise, has done much to further the study of Irish Taraxacum in recent years.

Taraxacum dudmanianum A.J. Richards sp. nov.

Holotype: On verge on west side of road adjacent to NE corner of grass, chapel car park, Salem Chapel, Whitemill, Carmarthenshire (v.c.44), SN46552260, 03/05/2019, R.D. Pryce no. 1901; NMW. (Fig. 3).

Plant large with erect, somewhat crisped, heterophyllous leaves. Leaves rather pale green, broadly oblanceolate, unblotched, scarcely hairy, mid-rib green; petioles unwinged to narrowly winged at the base, inner pale pink, outer pallid. Lateral leaflobes 3-4, broad, recurved, acuminate, sometimes interspersed with a single tooth, dentate at least on proximal lobes. Terminal leaf-lobes rather short, rounded with an acuminate apex on outer leaves, much larger, to half length of leaf, helmet-shaped and with an acuminate to shortly extenuate and acute apex on inner leaves. Scapes exceeding leaves, greenish, sparsely hairy. Exterior bracts $11-14 \times 3.0-3.5 \mathrm{~mm}$, recurved, acute and the outer semi-circular in posture ('claw-shaped'), pale green above, unbordered. Capitula $50 \mathrm{~mm}$ diameter, deep yellow. Ligules striped grey- 
violet, teeth yellow. Stigmas dark yellow, drying discoloured; pollen plentiful. Achene body $3.0 \mathrm{~mm}$, straw-coloured; cone $0.5 \mathrm{~mm}$.

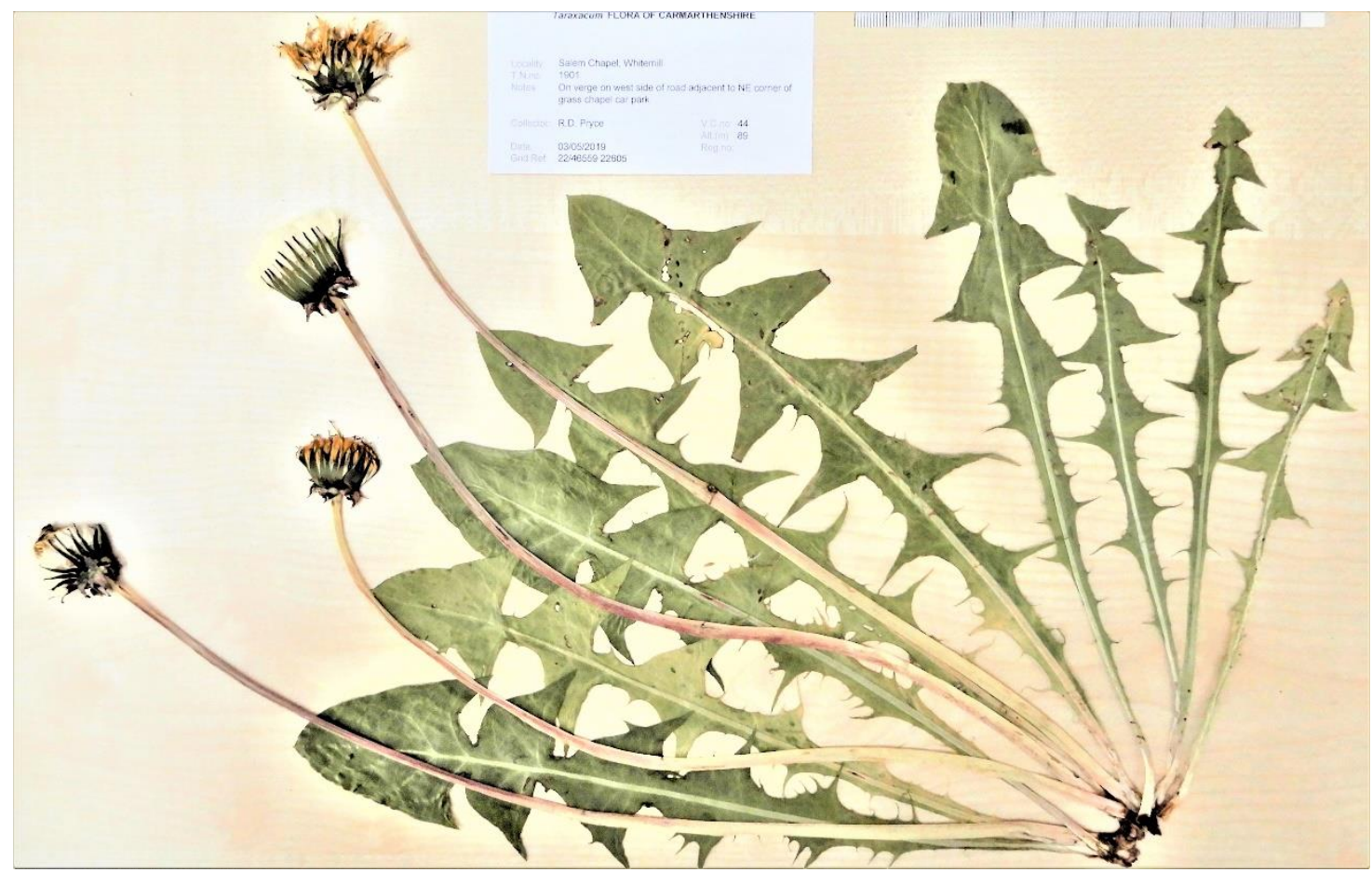

Figure 3. Holotype of T. dudmanianum (NMW). Image: Richard Pryce.

This section Taraxacum (previously known as section Ruderalia Kirschner, $\mathrm{H}$. Øllg. \& Štěpánek) taxon has been known in Britain and Ireland as T. aberrans Hagend., Soest \& Zevenb. (1974) for four decades, and before that as $T$. caudatulum Dahlst. (Dudman \& Richards, 1997). However, it is clear from the type description and figures from the website taraxacumnederland.nl that it is not $T$. aberrans. It appears to be identical to the taraxacumnederland.nl figures of $T$. breviflorum Dahlst. (Fig. 4).

However, online representations of the lectotype of $T$. breviflorum $(\mathbf{S})$ are of another taxon. The British and Irish plant is familiar, widespread and not uncommon in our islands, but at present we have no valid name for it. Although it may well be recognized elsewhere in Europe, I have not been able to find its counterpart after widespread enquiries, although clearly it also occurs in the Netherlands without a valid name. Amongst recognised British and Irish species, it comes close to $T$. pseudoretroflexum M.P. Christ. in section Taraxacum. It differs principally by the notably claw-shaped (half-recoiled) exterior bracts, and the larger, more rounded terminal leaf lobes to the inner leaves. 


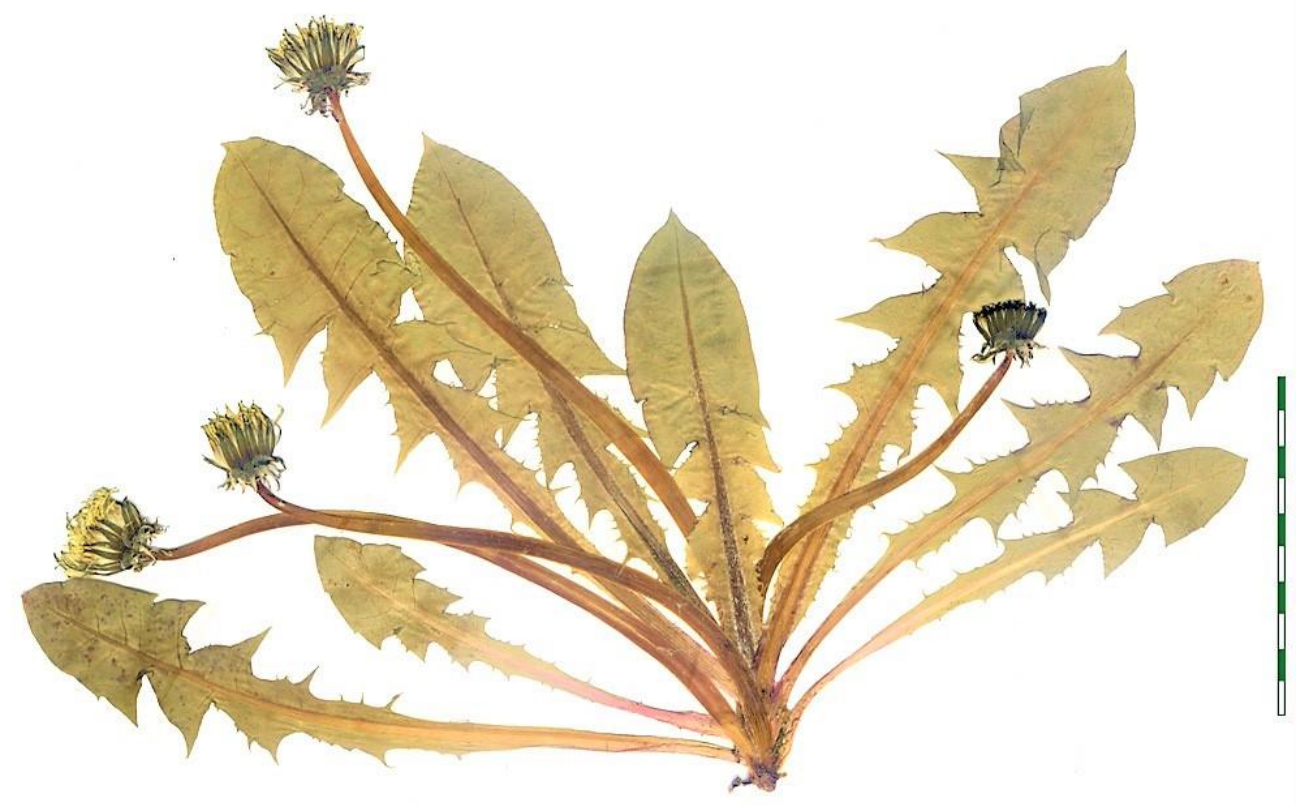

Figure 4. Plant represented on the taraxacumnederland.nl website as Taraxacum breviflorum Dahlst., considered to be T. dudmanianum.

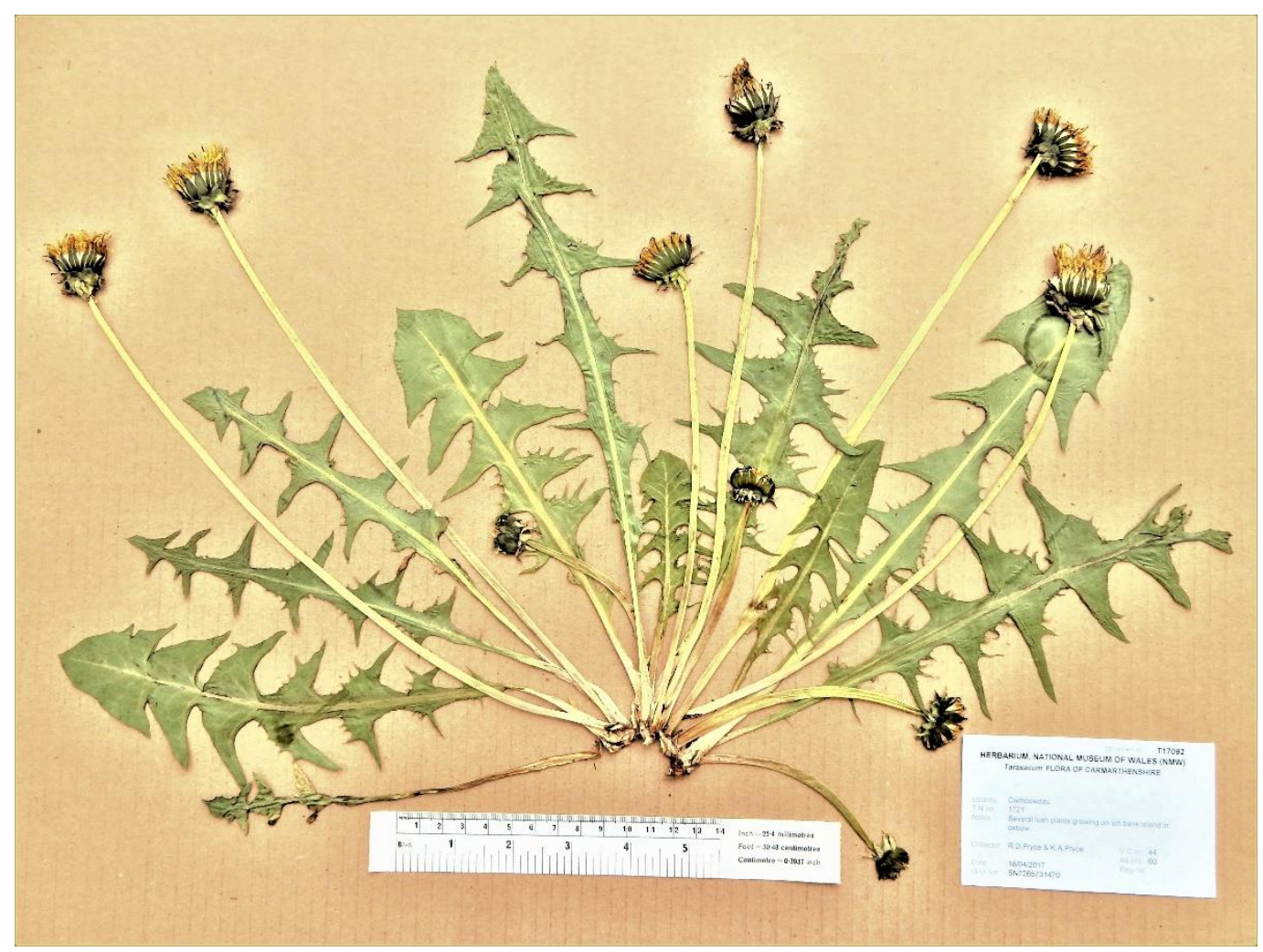

Figure 5. A representative collection of T. dudmanianum: several lush plants growing on silt bank island in ox-bow, Cwmcowddu, Carmarthenshire (v.c.44), SN72653147, 18/04/2017, R.D. \& K.A. Pryce no. 1721; NMW. Image: Richard Pryce. 
Taraxacum dudmanianum has winged petioles which are pink on the inner leaves and whitish on the outer leaves (Fig. 6), and heterophyllous leaves in which the terminal leaf-lobe is much larger in inner leaves than outer leaves at flowering time (Figs. 3 and 5). This places it in the informal group Ekmania of section Taraxacum in Richards (2021). In addition, like the familiar and common T. ekmanii Dahlst., it has pale green, rather flaccid leaves. However, $T$. dudmanianum has a short apiculate apex to the large terminal lobes to the inner leaves, and lacks the semi-lunate, somewhat sigmoid lateral lobes of the outer leaves of T. ekmanii. Distinctively, the outer exterior bracts have a semi-recoiled posture to give a talonlike shape (Fig. 7), an unusual feature which is best known in the otherwise very dissimilar T. polyodon Dahlst. This feature is the best discriminant in comparison with $T$. pseudoretroflexum, as noted above, although the two species differ in leafshape.

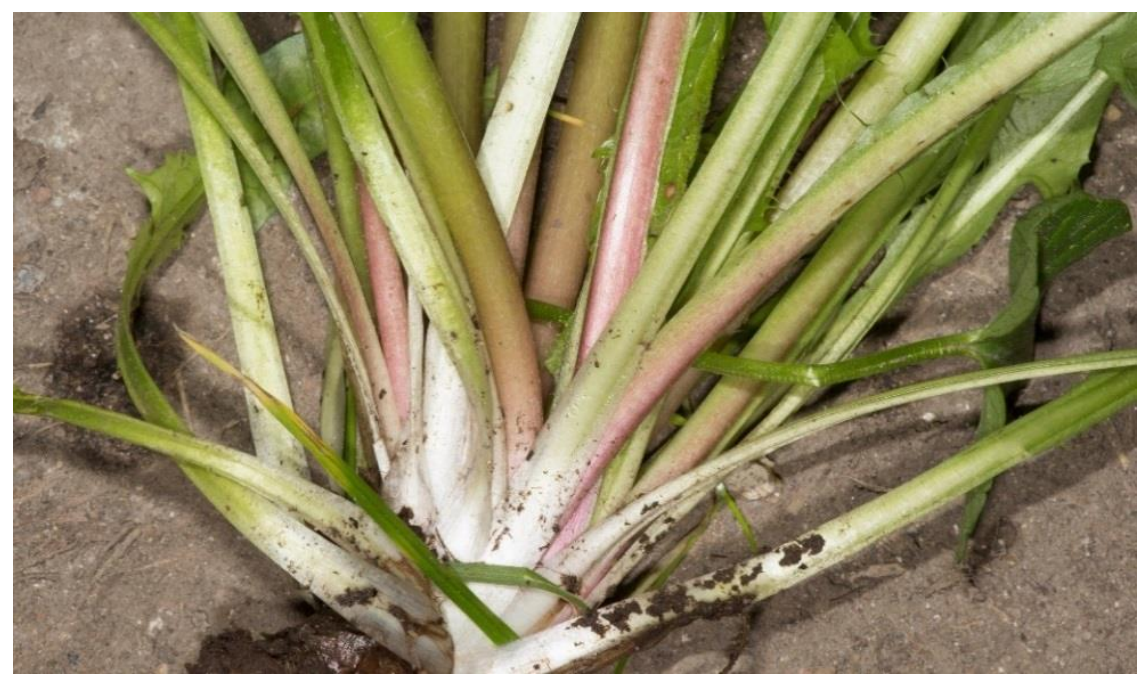

Figure 6. Petioles of T. dudmanianum, unwinged to narrowly winged and pink on the inner leaves, white on the outer leaves. Image: Mark Lynes.

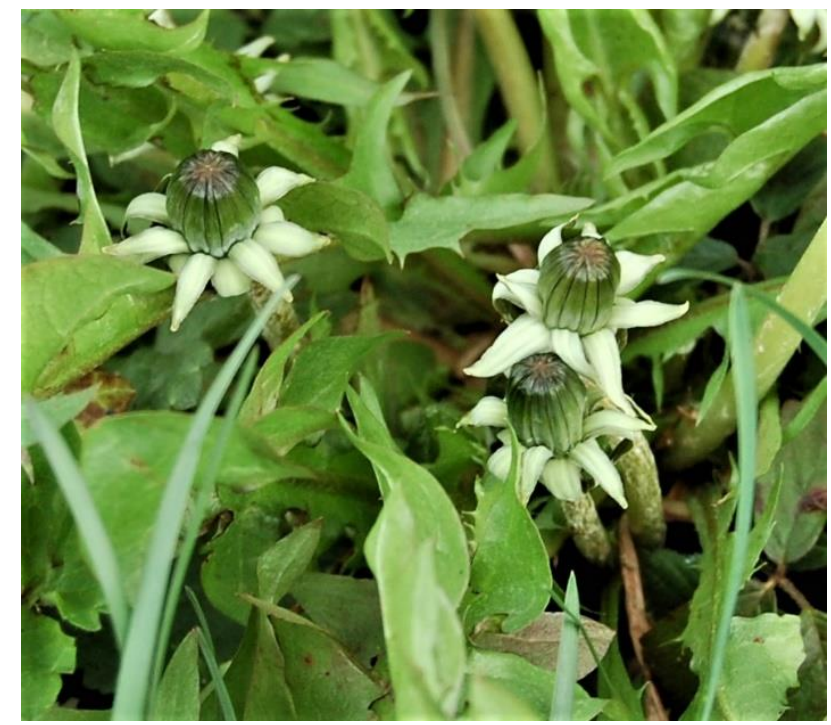

Figure 7. Bud involucres of $T$. dudmanianum, showing recoiled outer exterior bracts. Image: Photo Tim Rich 
Taraxacum dudmanianum is scattered through Britain from Devon to southeast Scotland, with three records in eastern Ireland where it may be introduced (Table 1; Fig. 8). It apparently occurs in the Netherlands, but as yet its distribution outside Britain and Ireland is uncertain. Like most members of section Taraxacum it favours anthropogenic habitats, road-verges and banks, hedge-rows, gardens and waste-places, although it may also occur in open semi-natural habitats.

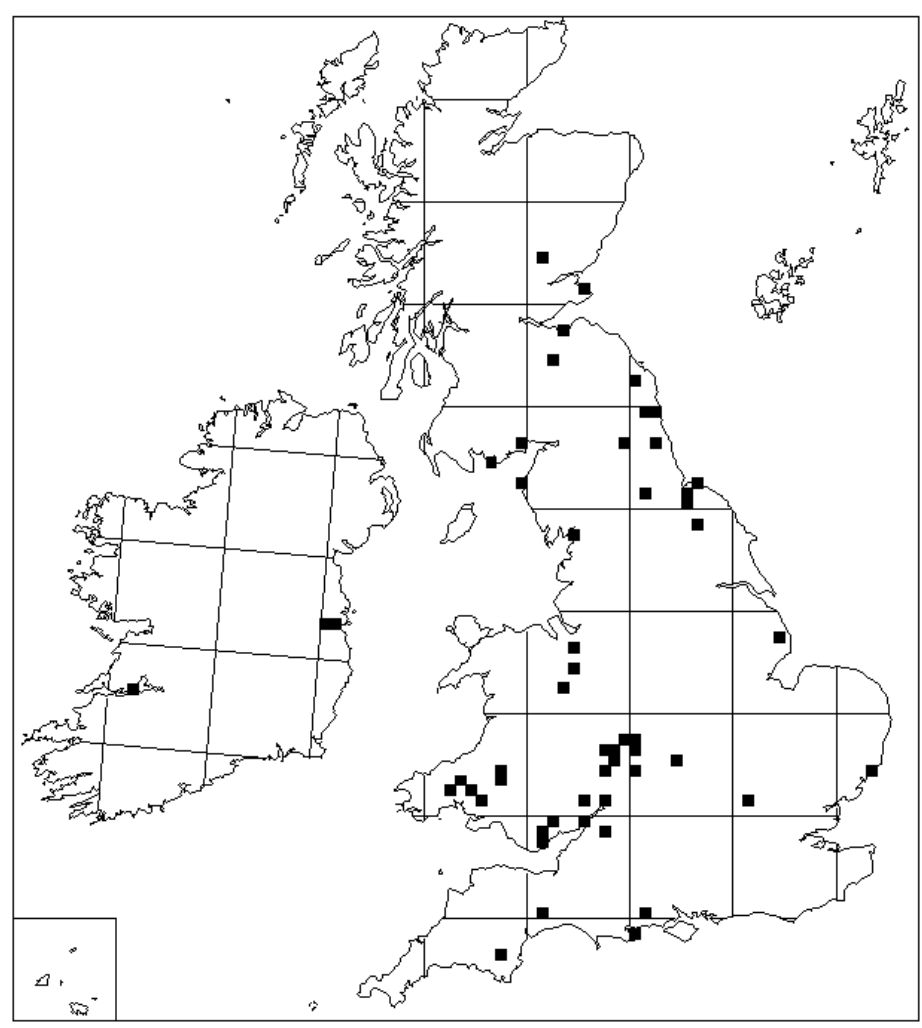

Figure 8. Distribution map of T. dudmanianum

Table 1. List of British and Irish records for T. dudmanianum authenticated by the author. Many are site records, or identified from photographs.

\begin{tabular}{|l|l|l|l|l|}
\hline V.c. & $\begin{array}{l}\text { Grid } \\
\text { reference }\end{array}$ & Locality & Collector & Date \\
\hline 3 & ST1401 & Between Honiton \& Awliscombe & Margetts L.J. & $26 / 04 / 1992$ \\
\hline 3 & ST1500 & Tracey Bridge, Honiton & Margetts L.J. & $02 / 05 / 1993$ \\
\hline 3 & ST1501 & Tracey Bridge, Honiton & Margetts L.J. & $12 / 04 / 1991$ \\
\hline 3 & SX750689 & Lane to Pridhamsleigh & Day J.J. & $03 / 05 / 2018$ \\
\hline 9 & SZ018811 & Swanage & Leadbetter, & $16 / 04 / 2020$ \\
D. & \\
\hline 11 & SU147049 & Bickerley Common, Ringwood & Richards A.J. & $19 / 04 / 2015$ \\
\hline 20 & TL110123 & Redbourn & Richards A.J. & $15 / 04 / 2002$ \\
\hline 23 & SP487596 & Godstow Rd., Wolvercote & Flora Oxon & $01 / 05 / 1999$ \\
\hline 25 & TM3347 & Upper Hollesly Common & Heath J.J. & $08 / 05 / 1992$ \\
\hline 33 & SO786123 & Hardwicke & Marsden M. & $10 / 05 / 1991$ \\
\hline
\end{tabular}




\begin{tabular}{|c|c|c|c|c|}
\hline 34 & ST551904 & under Severn Bridge \& Beachley Head & Richards A.J. & $04 / 05 / 1996$ \\
\hline 34 & ST7986 & Swangrove & Rooney P. & 29/04/1989 \\
\hline 35 & SO5210 & Near Penallt Old Church - verge & Evans T.G. & $19 / 04 / 1999$ \\
\hline 35 & ST246991 & A472, Craig Gwent - verge & Evans T.G. & $30 / 04 / 2001$ \\
\hline 36 & SO572193 & Goodrich & Marsden M. & $25 / 04 / 1998$ \\
\hline 37 & SO764458 & West Malvern & Garner P.G. & $27 / 04 / 1999$ \\
\hline 37 & SO788604 & Venn Lane Wichenford - grass verge & Day J.J. & $21 / 04 / 2012$ \\
\hline 37 & SO861521 & A4440 Broomhill Way - grassy verge & Reid A.W. & $10 / 04 / 2012$ \\
\hline 37 & SO887636 & Droitwich by-pass & Reid A.W. & $25 / 04 / 1998$ \\
\hline 37 & SO890556 & $\begin{array}{l}\text { Trotshill Lane (disused section) - grass } \\
\text { verge }\end{array}$ & Day J.J. & $01 / 05 / 2007$ \\
\hline 37 & SO946778 & Sling pool - wood pasture W side & Day J.J. & $11 / 05 / 2005$ \\
\hline 37 & SP023625 & Crofts Lane Astwood - grass verge & Day J.J. & $30 / 03 / 2008$ \\
\hline 37 & SP023711 & $\begin{array}{l}\text { Field south of Grange Lane, Cobley - } \\
\text { grass bank }\end{array}$ & Day J.J. & $11 / 04 / 2010$ \\
\hline 37 & SP036432 & Avonside, Hampton & Knight, T.D. & $19 / 04 / 1999$ \\
\hline 40 & SJ32 & Bagley & $\begin{array}{l}\text { Edmondson } \\
\mathrm{T} \text {. }\end{array}$ & 1978 \\
\hline 41 & ST120825 & A4054 below Castle Coch, Tongwynlias & Rich T.C.G. & $06 / 04 / 2008$ \\
\hline 41 & ST174778 & $\begin{array}{l}\text { Maindy, path west of Marlborough } \\
\text { Terrace }\end{array}$ & Rich T.C.G. & $13 / 04 / 2010$ \\
\hline 42 & SN565163 & Coetir Bach & Pryce R.D. & $07 / 05 / 2015$ \\
\hline 44 & SN246253 & $\begin{array}{l}1 \mathrm{~km} \text { SW of Cwmbach - grassy roadside } \\
\text { bank }\end{array}$ & $\begin{array}{l}\text { Hutchinson } \\
\text { G. \& Pryce } \\
\text { R.D. }\end{array}$ & 26/04/1995 \\
\hline 44 & SN353333 & Gorllwyn - roadside bank, side of ravine & Pryce R.D. & $25 / 04 / 1992$ \\
\hline 44 & SN782436 & Rhandirnwyn Mine & Pryce R.D. & $24 / 04 / 1993$ \\
\hline 54 & TF471719 & Willoughby Village & Lynes, M. & $01 / 04 / 2017$ \\
\hline 58 & SJ46 & Little Barrow & $\begin{array}{l}\text { Edmondson } \\
\text { T. }\end{array}$ & 1979 \\
\hline 58 & SJ430487 & Shocklach Green & $\begin{array}{l}\text { Edmondson } \\
\text { T. }\end{array}$ & $13 / 05 / 1988$ \\
\hline 62 & NZ504052 & A172, by road to Carlton - road verge & Jones V. & $23 / 04 / 2010$ \\
\hline 62 & NZ513116 & Howe Bank SE of Newby - E road verge & Jones V. & $14 / 05 / 2013$ \\
\hline 62 & NZ551173 & Flatts Lane - meadow & Jones V. & 29/04/1993 \\
\hline 62 & NZ562110 & $\begin{array}{l}\text { Romanby Road, Great Ayton - waste } \\
\text { ground, back alley at north end }\end{array}$ & Jones V. & $21 / 04 / 2009$ \\
\hline 62 & NZ582157 & $\begin{array}{l}\text { S of Windle Bridge Garden Centre - } \\
\text { waste ground by lane }\end{array}$ & Jones V. & $28 / 04 / 2012$ \\
\hline 62 & NZ583064 & $\begin{array}{l}\text { Ingleby Greenhow - road verge by } \\
\text { vicarage }\end{array}$ & Jones V. & $05 / 05 / 2008$ \\
\hline 62 & NZ633221 & $\begin{array}{l}\text { Raisbeck Gardens, Marske - waste } \\
\text { ground at edge of footpath }\end{array}$ & Jones V. & $10 / 04 / 2012$ \\
\hline 62 & SE613879 & Carlton Park Farm, Helmsley - verge & Jones V. & $04 / 05 / 1997$ \\
\hline 66 & NZ1115 & Whorlton laneside & Jones V. & $30 / 04 / 1995$ \\
\hline 67 & NY920643 & Hexham & Richards A.J. & 1979 \\
\hline
\end{tabular}




\begin{tabular}{|l|l|l|l|l|}
\hline 67 & NZ1595 & Longhorsley & Richards A.J. & $08 / 05 / 1982$ \\
\hline 67 & NZ217960 & Chevington Moor & Richards A.J. & 1980 \\
\hline 67 & NZ246655 & Newcastle upon Tyne & Richards A.J. & 1979 \\
\hline 68 & NU0025 & Haugh Head & Richards A.J. & 1979 \\
\hline 69 & SD427788 & Meahop near Grange-Over-Sands & Boucher A.M. & 2012 \\
\hline 70 & NX9828 & Workington church & Dudman A.A. & $19 / 05 / 1991$ \\
\hline 70 & NX9828 & Workington Docks & Dudman A.A. & $08 / 05 / 1991$ \\
\hline 73 & NX6145 & Borness & Stewart O.M. & $19 / 05 / 1996$ \\
\hline 73 & NX9766 & West Maryfield, New Abbey & Stewart O.M. & $12 / 05 / 1990$ \\
\hline 78 & NT263405 & Soonhope Burn & $\begin{array}{l}\text { Pankhurst } \\
\text { R.J. }\end{array}$ & $21 / 05 / 1999$ \\
\hline 83 & NT308735 & Portobello, Harry Lauder Way & $\begin{array}{l}\text { Pankhurst } \\
\text { R.J. }\end{array}$ & $09 / 05 / 1998$ \\
\hline 85 & NO599127 & Kingsbarns - bank & $\begin{array}{l}\text { Pankhurst } \\
\text { R.J. }\end{array}$ & $30 / 04 / 2006$ \\
\hline 89 & N0179450 & $\begin{array}{l}\text { Blairgowrie - road verge and A93 } \\
\text { Bankhead railings }\end{array}$ & Rich T.C.G. & $11 / 05 / 2013$ \\
\hline H8 & R246518 & Foynes & Reynolds S. & $18 / 03 / 2019$ \\
\hline H21 & $\mathbf{0 0 2 8 3 6 1}$ & $\begin{array}{l}\text { St. Catherines estate/woodland, Lucan, } \\
\text { Dublin }\end{array}$ & Fitzgerald R. & $07 / 04 / 2020$ \\
\hline H21 & 01437 & Cremore Villas, Glasnevin & Doogue D. & $17 / 04 / 2020$ \\
\hline
\end{tabular}

Taraxacum dudmanianum is named in memory of the late Andrew Dudman, co-author of Dandelions of Great Britain and Ireland (Dudman \& Richards 1997).

\section{Acknowledgements}

The maps were plotted using DMAPW by Alan Morton. Tim Rich made many useful suggestions and helpfully edited and partially rewrote a first draft. My indebtedness to Declan Doogue is recorded above.

\section{References}

Dudman, A.A. \& Richards, A.J. 1997. Dandelions of Great Britain and Ireland. BSBI Handbook 9. London: Botanical Society of the British Isles.

Hagendijk, A., Soest, J.L. van \& Zevenbergen, H. 1974. Neue Taraxacumarten der Niederlande. III. Acta botanica neerlandica 23: 439-459.

Richards, A.J. 2021. Field Handbook to British and Irish Dandelions. BSBI Handbook 23. Durham: Botanical Society of Britain and Ireland.

Richards, A.J. \& Doogue, D. 2017. Notes on some Taraxacum (Asteraceae) from Ireland including description of four new species in section Celtica. New Journal of Botany 7: 136-146.

Copyright retained by author(s). Published by BSBI under the terms of the Creative Commons Attribution 4.0 International Public License.

ISSN: $2632-4970$

https://doi.org/10.33928/bib.2021.03.324 